\title{
Endotoxins from a Pharmacopoeial Point of View
}

\author{
Elvira Franco ${ }^{1,2,+}$, Verónica Garcia-Recio ${ }^{1,+}+$ (D) , Pilar Jiménez ${ }^{3}$, Manuel Garrosa 4 (1) \\ Tomás Girbés ${ }^{3}$, Manuel Cordoba-Diaz ${ }^{1,2, * \text { (D) }}$ and Damián Cordoba-Diaz 1,2,* (iD \\ 1 Pharmaceutics and Food Technology, Complutense University of Madrid, 28040 Madrid, Spain; \\ elvirafg@farm.ucm.es (E.F.); vgrecio@ucm.es (V.G.-R.) \\ 2 University Institute of Industrial Pharmacy (IUFI), Complutense University of Madrid, 28040 Madrid, Spain \\ 3 Area of Nutrition and Food Sciences, University of Valladolid, 47005 Valladolid, Spain; \\ pilarj@bio.uva.es (P.J.); girbes@bio.uva.es (T.G.) \\ 4 Area of Histology, Faculty of Medicine and INCYL, University of Valladolid, 47005 Valladolid, Spain; \\ garrosa@med.uva.es \\ * Correspondence: mcordoba@farm.ucm.es (M.C.-D.); damianco@farm.ucm.es (D.C.-D.); \\ Tel.: +34-91-394-7243 (M.C.-D. \& D.C.-D.) \\ + These authors contributed equally to this work.
}

Received: 30 June 2018; Accepted: 14 August 2018; Published: 16 August 2018

\begin{abstract}
A pyrogen is a substance that causes fever after intravenous administration or inhalation. Gram negative endotoxins are the most important pyrogens to pharmaceutical laboratories. In the International, United States, Japanese and European Pharmacopoeias, there are two official methods to evaluate pyrogenicity - that is, the bacterial endotoxin test, and the pyrogen test. The main objective of this review is to compare the monographs of each test among the different Pharmacopeias, to detect similarities and differences. The former can be considered fully harmonized, and only non-significant differences were detected. The latter, which is the only available assay for some products and formulations to demonstrate apyrogenicity, shows large differences, which should be considered.
\end{abstract}

Keywords: endotoxins; pyrogens; parenteral drug products; pharmacopoeial test; harmonization

Key Contribution: The bacterial endotoxin test is completely harmonized in the ICH region, but the pyrogen test shows large differences which should be considered by pharmaceutical laboratories from a regulatory point of view.

\section{Introduction}

Pyrogens are defined as substances that cause exacerbate febrile reactions when sufficient amounts gain access to the circulatory system after parenteral administration or inhalation. Although "pyrogen" is a general term to define fever-producing agents (Figure 1), it is frequently used to specifically describe Gram-negative bacteria (GNB) endotoxins in the pharmaceutical industry. Other pyrogenic substances can occur, although the risks are lower [1].

GNB endotoxin is a high molecular weight complex that contains lipopolysaccharide (LPS), protein, and phospholipid originating from the outer membrane of Gram-negative bacteria. Most pharmacopoeial endotoxin reference standards should be more correctly described as purified LPS since its chemical nature after purification is a lipid component called Lipid A, covalently bound to a polysaccharide composed of two parts, the core and a variable O-specific side chain, responsible for the specific immune reaction evoked in the host. 


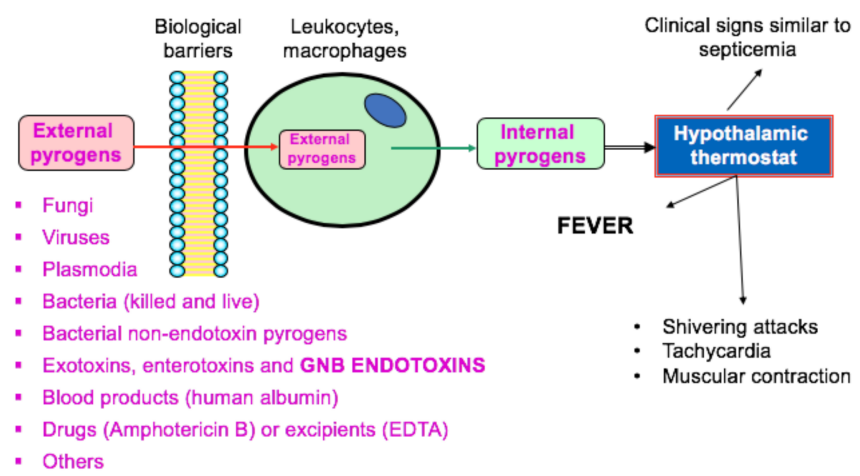

Figure 1. Most significant pyrogens for pharmaceutical manufacturers and sequential events of fever. GNB = Gram-negative bacteria .

Depyrogenation is one of the most important challenges for pharmaceutical manufactures of parenteral drugs, since fever in a patient depends on the total amount of pyrogen delivered to that patient. Dry heat at temperatures above $180^{\circ} \mathrm{C}$ is the method of choice for heat-resistant products, since GNB endotoxins are thermostable in the presence of moist heat and are not significantly destroyed by conventional autoclaving processes [2]. Moreover, another interesting property of GNB endotoxin is its tendency to aggregate into vesicles due to the attraction between hydrophobic groups of the LPS. These vesicles are large enough to be removed by reverse-osmosis processes or size exclusion chromatography. It should be considered, that in an aqueous environment the endotoxin aggregation state depends on its surrounding environment, i.e., divalent cations such as calcium or magnesium forms larger, more stable and lower soluble endotoxin aggregates. This property can be of particular interest in depyrogenation by ultrafiltration processes. Utilizing the electrostatic properties of GNB endotoxin can offer another interesting alternative for depyrogenation. It has been described that endotoxins are positively charged at $\mathrm{pH}$ levels above 5 , and negatively charged at $\mathrm{pH}$ levels under 2 . This property is very useful since it accounts for the attraction that GNB endotoxins have for stationary phases in chromatographic isolation [3].

The origins of the rabbit pyrogen test data back to studies by Seibert, who developed a mammalian test between 1923 and 1925, in response to concerns from surgeons about fever [4]. In 1943, Welch and coworkers published two reference papers outlining the results of a collaborative study performed by the U.S. Food \& Drug Administration (FDA), the National Institutes of Health (NIH), and several pharmaceutical companies [5,6], resulting in the first rabbit pyrogen test (RPT) to be included in the United States Pharmacopoeia (USP). The current USP monograph, based on the evaluation of the rectal temperature of rabbits before and after an intravenous injection of a test solution into the ear, is not substantially different from the original one.

The bacterial endotoxin test (BET) —also known as LAL-test—is an alternative in vitro endotoxin assay, accepted by the main regulatory drug agencies (FDA, European Medicines Agency (EMA) or Pharmaceuticals and Medical Devices Agency (PMDA), among others). There are three techniques to perform this test, all of them based on the Limulus amebocyte lysate (LAL). In 1964, Levin and Bang first recognized the coagulation of the lysate in the presence of GNB endotoxin $[7,8]$. However, some complex formulations such as radiopharmaceuticals, biotechnology formulations, etc. cannot be assayed by BET. Despite scientist having proposed several in vitro methods which are faster and more easily automated than the original LAL-tests of Cooper and Mills, the latter still remains the only official in the main pharmacopeias [9-17].

FDA and EMA have considered the monocyte activation test (MAT) as a humane alternative method to RPT $[18,19]$. The assay involves incubating a diluted test sample with a source of human monocytes or human monocytoid cells. Monocytes activated by pyrogens produce cytokines/interleukins that are detected in an immunological assay. Human whole blood, peripheral blood mononuclear cells (PBMC) 
or monocytic cell lines, are appropriate sources of monocytes and are commercially available [20-24]. As MAT has higher sensitivity and accuracy than RPT, promises to replace it in the near future.

Although some interesting reviews about the RPT and the BET were previously published, to our knowledge, none of them provide an in-depth comparison of the two currently available official methods to evaluate pyrogenicity (RPT and BET). The goal of this review is to highlight the differences and similarities of each assay throughout the USP, European Pharmacopoeia (EP), Japanese Pharmacopoeia (JP) and International Pharmacopoeia (IP), taking into account the current thinking of the regulatory authorities, as well as the suggestions and recommendations of the International Council for Harmonisation of Technical Requirements for Pharmaceuticals for Human Use (ICH).

\section{In Vivo Pyrogen Assay: Rabbit Pyrogen Test (RPT)}

In Tables 1-4, comparative specifications, procedures, and characteristics have been extracted from the official monographs regarding animals and good laboratory practice (GLP) conditions, temperature recording, acceptance criteria, and judgement [25-28].

Table 1. Experimental conditions referring to animals involved in the assay.

\begin{tabular}{|c|c|c|c|c|}
\hline Experimental & IP & USP & $\mathrm{JP}$ & EP \\
\hline Number & 3 & 3 & 3 & 3 \\
\hline Condition & Healthy & Healthy & Healthy & Healthy \\
\hline Age & Adult & Mature & Mature & Adult \\
\hline Variety & The same, ideally & - & - & - \\
\hline \multicolumn{5}{|l|}{ Housing: } \\
\hline feeding & usual food ad libitum & - & constant diet & complete, balanced, antibiotics free diet \\
\hline Environs & Not exciting & Not exciting & Not exciting & Quiet \\
\hline Individually or in group & Individually & Individually & Individually & Individually \\
\hline Rejection reasons & $\begin{array}{l}\text { - Last use, in a pyrogen test, } \\
\text { in the last } 48 \mathrm{~h} \\
\text { - T rise in the last test } \geq 0.5^{\circ} \mathrm{C} \\
\text { - Last use in a } \\
\text { pyrogen-positive test in the } \\
\text { previous } 2 \text { weeks }\end{array}$ & $\begin{array}{l}\text { - Last use, in a pyrogen test, } \\
\text { in the last } 48 \mathrm{~h} \\
\text { - T rise } \geq 0.6^{\circ} \mathrm{C} \text { in a pyrogen } \\
\text { test in the previous } 2 \text { weeks } \\
\text { - Last use in a } \\
\text { pyrogen-positive test in the } \\
\text { previous } 2 \text { weeks }\end{array}$ & $\begin{array}{l}\text { - Last use, in a pyrogen } \\
\text { test, in the last } 48 \mathrm{~h} \\
\text { - Last use in a } \\
\text { pyrogen-positive test } \\
\text { - Loss of body mass in the } \\
\text { previous week }\end{array}$ & $\begin{array}{l}\text { - Loss of body mass in the previous week } \\
\text { - Last use, in a pyrogen test, in the last } 3 \text { days } \\
\text { - Last use, in a pyrogen-positive test, in the } \\
\text { last } 3 \text { weeks } \\
\text { - Use, in a pyrogen test, where the rabbits' } \\
\text { temperature mean rise }>1.2^{\circ} \mathrm{C}\end{array}$ \\
\hline
\end{tabular}

Among the evaluated pharmacopoeias, the most significant differences related to the experimental conditions for the animals involved in the assay are housing temperature (USP and JP the most restrictive), feeding during housing (only the EP demands a diet without antibiotics), and initial rabbit rejection reasons (the IP and the EP are the most restrictive). 
Table 2. Experimental conditions referring to temperature recording in the rabbit pyrogen test (RPT)

\begin{tabular}{|c|c|c|c|c|}
\hline Experimental & IP & USP & JP & EP \\
\hline Test room & $\begin{array}{l}\text { Housing area or similar } \\
\text { separate room }\end{array}$ & $\begin{array}{l}\text { Separate area designated solely for } \\
\text { pyrogen testing }\end{array}$ & Separate room & $\begin{array}{l}\text { Housing area or separate } \\
\text { room (at least } 18 \mathrm{~h} \text { of previous staying) }\end{array}$ \\
\hline Room T & Similar to the housing $\mathrm{T}$ & Similar to the housing $\mathrm{T}$ & Similar to the housing $\mathrm{T}$ & Within $3{ }^{\circ} \mathrm{C}$ of the housing $\mathrm{T}$ \\
\hline Instrument & $\begin{array}{l}\text { Accurate thermometer or } \\
\text { T-recording device }\end{array}$ & $\begin{array}{l}\text { Accurate T-sensing device } \\
\text { (clinical thermometer or thermistor probe) }\end{array}$ & $\begin{array}{l}\text { Rectal thermometer or } \\
\text { T-measuring apparatus }\end{array}$ & Thermometer or electrical device \\
\hline Precision & $0.1^{\circ} \mathrm{C}$ & $\pm 0.1^{\circ} \mathrm{C}$ & $\leq \pm 0.1^{\circ} \mathrm{C}$ & $0.1^{\circ} \mathrm{C}$ \\
\hline Time & Sufficient to reach a maximum $\mathrm{T}$ & $\begin{array}{l}\text { Sufficient to reach a maximum } \\
\mathrm{T} \text { and }<5 \mathrm{~min}\end{array}$ & - & $\begin{array}{l}\text { An electrical device may be left throughout } \\
\text { the test. }\end{array}$ \\
\hline Site and depth & Rectum, $\approx 6 \mathrm{~cm}$ & Rectum, $\geq 7.5 \mathrm{~cm}$ & Rectum, 6-9 cm constant & Rectum, $\approx 5 \mathrm{~cm}$ constant \\
\hline Restraint & By a loosely fitting neck stock & With lightly fitting neck stock & By a loosely fitting neck stock & $\begin{array}{l}\text { By a loosely fitting neck stock } \\
\text { (at least } 1 \mathrm{~h} \text { before and throughout the test) }\end{array}$ \\
\hline Posture & Natural resting & Natural resting & Natural resting & Normal \\
\hline Feeding & $\begin{array}{l}\text { Not allowed } \\
(2 \mathrm{~h} \text { before and during test })\end{array}$ & Not allowed & $\begin{array}{l}\text { Not allowed } \\
\text { (several hours before and during test) }\end{array}$ & $\begin{array}{l}\text { Not allowed } \\
\text { (previous overnight and during test) }\end{array}$ \\
\hline Watering & Allowed & Allowed, may be restricted & - & Not allowed \\
\hline
\end{tabular}

T: temperature; IP: International Pharmacopoeia; USP: United States Pharmacopoeia; JP: Japanese Pharmacopoeia; EP: European Pharmacopoeia.

For the experimental conditions regarding temperature recording, the most important differences among the selected pharmacopoeias are: the depth of the temperature recorder device, the feeding and the watering. These factors can influence the obtained results significantly. 
Table 3. RPT procedure.

\begin{tabular}{|c|c|c|c|c|}
\hline Experimental & IP & USP & JP & EP \\
\hline $\begin{array}{l}\text { Pretraining for rabbits not } \\
\text { previously used }\end{array}$ & $\begin{array}{l}\text { Same test omitting the injection, } \\
1-3 \text { days before }\end{array}$ & $\begin{array}{l}\text { Same test omitting the injection, not } \\
\text { more than } 7 \text { days before; for rabbits } \\
\text { never used before }\end{array}$ & $\begin{array}{l}\text { Same test omitting the injection, } \\
1-3 \text { days before }\end{array}$ & $\begin{array}{l}\text { Same test injecting pyrogen-free } 9 \mathrm{~g} / \mathrm{L} \text { solution } \\
\text { of sodium chloride R, } 1-3 \text { days before. } \\
\text { Non-use period = } 2 \text { weeks }\end{array}$ \\
\hline Pre-injection conditioning time & $\geq 1 \mathrm{~h}$ & - & $\geq 48 \mathrm{~h}$ & $18 \mathrm{~h}$ \\
\hline Control T (CT) & $\begin{array}{l}\text { Mean of two T readings (T1, T2) at an } \\
\text { interval of } 30 \text { min in the } 40 \mathrm{~min} \\
\text { preceding the injection }\end{array}$ & $\begin{array}{l}\text { Taken no more than } 30 \mathrm{~min} \text { prior to the } \\
\text { injection }\end{array}$ & $\begin{array}{l}\text { Mean of two T readings (T1, T2) at } \\
\text { an interval of } 30 \text { min in the } 40 \mathrm{~min} \\
\text { preceding the injection }\end{array}$ & $\begin{array}{l}\text { Mean of two } \mathrm{T} \text { readings }(\mathrm{T} 1, \mathrm{~T} 2) \text { at an interval of } \\
30 \mathrm{~min} \text { in the } 40 \mathrm{~min} \text { preceding the injection }\end{array}$ \\
\hline Rabbit selection criteria & $\begin{array}{l}\text { - } \triangle \mathrm{CT} \text { among rabbits } \leq 1.0^{\circ} \mathrm{C} \\
\text { - T1-T2 } \leq \text { mean } \pm 0.2^{\circ} \mathrm{C} \\
\text { - } 38^{\circ} \mathrm{C} \leq \mathrm{CT} \leq 39.8{ }^{\circ} \mathrm{C}\end{array}$ & $\begin{array}{l}\text { - } \triangle \mathrm{CT} \text { among rabbits } \leq 1.0^{\circ} \mathrm{C} \\
\text { - } \mathrm{CT}<39.8^{\circ} \mathrm{C}\end{array}$ & $\begin{array}{l}\text { - } \mathrm{T} 1-\mathrm{T} 2 \leq \pm 0.2^{\circ} \mathrm{C} \\
\text {. } \mathrm{CT} \leq 39.8^{\circ} \mathrm{C}\end{array}$ & $\begin{array}{l}\text { - } \Delta \mathrm{T} \leq 0.6^{\circ} \mathrm{C} \text { in the pretraining } \\
\text { - T1-T2 } \leq \pm 0.2^{\circ} \mathrm{C} \\
-38^{\circ} \mathrm{C} \leq \mathrm{CT} \leq 39.8^{\circ} \mathrm{C} \\
. \Delta \mathrm{CT} \text { among rabbits } \leq 1.0^{\circ} \mathrm{C}\end{array}$ \\
\hline Syringe, needle and glassware & $\begin{array}{l}\text { Free of pyrogens by any suitable method } \\
\left(250^{\circ} \mathrm{C}, 30 \mathrm{~min}\right)\end{array}$ & $\begin{array}{l}\text { Free of pyrogens by any suitable method } \\
\left(250^{\circ} \mathrm{C}, 30 \mathrm{~min}\right)\end{array}$ & Free of pyrogens & $\begin{array}{l}\text { Thorough wash and heating in a hot-air oven } \\
\left(250^{\circ} \mathrm{C}, 30 \mathrm{~min} \text { or } 200^{\circ} \mathrm{C}, 1 \mathrm{~h}\right)\end{array}$ \\
\hline Test material & $\begin{array}{l}\text { Solution of the substance } \\
\text { being examined }\end{array}$ & $\begin{array}{l}\text { Either the product or the product treated } \\
\text { as directed in the monograph }\end{array}$ & $\begin{array}{l}\text { Solution of the substance being } \\
\text { examined. When hypotonic, may } \\
\text { be made isotonic. }\end{array}$ & Sterile solution of the substance being examined \\
\hline Tested product amount & As specified in the monograph & As prescribed in the monograph & - & As prescribed in the monograph \\
\hline Volume injected & $\begin{array}{l}10 \mathrm{~mL} / \mathrm{kg} \text { (or as specified in } \\
\text { the monograph) }\end{array}$ & $\begin{array}{l}10 \mathrm{~mL} / \mathrm{kg} \text { (or as specified in the } \\
\text { monograph) }\end{array}$ & $\begin{array}{l}10 \mathrm{~mL} / \mathrm{kg} \text { (or as specified in } \\
\text { the monograph) }\end{array}$ & $0.5 \mathrm{~mL} / \mathrm{kg}-10 \mathrm{~mL} / \mathrm{kg}$ \\
\hline Test solution T & $\approx 38^{\circ} \mathrm{C}$ & $37^{\circ} \mathrm{C} \pm 2{ }^{\circ} \mathrm{C}$ & $37^{\circ} \mathrm{C} \pm 2{ }^{\circ} \mathrm{C}$ & $\approx 38^{\circ} \mathrm{C}$ \\
\hline Injection site & Marginal vein of the ear & Ear vein & Marginal vein of the ear & Marginal vein of the ear \\
\hline Injecting time & $\begin{array}{l}\leq 4 \mathrm{~min} \text { (or as specified in } \\
\text { the monograph) }\end{array}$ & $\leq 10 \min$ & $\leq 10 \mathrm{~min}$ & $\leq 4 \mathrm{~min}$ (or as specified in the monograph) \\
\hline Measurement period, after injection & $3 \mathrm{~h}$ & $3 \mathrm{~h}$ & $3 \mathrm{~h}$ & $3 \mathrm{~h}$ \\
\hline Measurement frequency & Continuously or every $30 \mathrm{~min}$ & $\begin{array}{l}\text { Every } 30 \mathrm{~min} \text { between } 1 \text { and } 3 \mathrm{~h} \\
\text { subsequent to the injection }\end{array}$ & $\leq 30 \mathrm{~min}$ & $\begin{array}{l}\leq 30 \mathrm{~min} \text { (starting at least } 90 \mathrm{~min} \text { before the } \\
\text { injection) }\end{array}$ \\
\hline Rabbit $\mathrm{T}$ rise $(\mathrm{TR})=$ response & $\begin{array}{l}-\mathrm{TR}=\mathrm{T}_{\max }-\mathrm{CT} \\
-\mathrm{TR}=0 \text { when } \mathrm{T}_{\max }<\mathrm{CT} \\
\left(\mathrm{T}_{\max }=\text { maximum } \mathrm{T} \text { recorded after }\right. \\
\text { injection/rabbit })\end{array}$ & $\begin{array}{l}-\mathrm{TR}=\mathrm{T}-\mathrm{CT} \\
-\mathrm{TR}=0 \text { when } \mathrm{T}<\mathrm{CT} \\
(\mathrm{T}=\text { any } \mathrm{T} \text { recorded after } \\
\text { injection/rabbit) }\end{array}$ & $\begin{array}{l}-\mathrm{TR}=\mathrm{T}_{\max }-\mathrm{CT} \\
-\mathrm{TR}=0 \text { when } \mathrm{T}_{\max }<\mathrm{CT} \\
\left(\mathrm{T}_{\max }=\text { maximum } \mathrm{T} \text { recorded after }\right. \\
\text { injection/rabbit) }\end{array}$ & $\begin{array}{l}-\mathrm{TR}=\mathrm{T}_{\max }-\mathrm{CT} \\
-\mathrm{TR}=0 \text { when } \mathrm{T}_{\max }<\mathrm{CT} \\
\left(\mathrm{T}_{\max }=\text { maximum } \mathrm{T} \text { recorded after }\right. \\
\text { injection/rabbit })\end{array}$ \\
\hline
\end{tabular}

T: temperature; IP: International Pharmacopoeia; USP: United States Pharmacopoeia; JP: Japanese Pharmacopoeia; EP: European Pharmacopoeia 
There are also important differences in the RPT procedure among the main pharmacopoeias. From our point of view, the most important ones are the pre-training, the pre-injection conditioning time and the injecting time.

Table 4. RPT acceptance criteria and judgement.

\begin{tabular}{|c|c|c|c|c|}
\hline Experimental & IP & USP & $\mathrm{JP}$ & EP \\
\hline $\begin{array}{l}\text { Number of rabbits } \\
\text { extra-groups }\end{array}$ & 1 & 1 & Up to 2 & Up to 3 \\
\hline Case 1 and judgment & $\begin{array}{l}\text { - No individual } \mathrm{TR} \geq 0.6^{\circ} \mathrm{C} \\
\text { and } \Sigma \mathrm{TR} \leq 1.4^{\circ} \mathrm{C} \\
\text { - Absence of pyrogens }\end{array}$ & $\begin{array}{l}\text { - No individual TR } \geq 0.5^{\circ} \mathrm{C} \\
\text { - Absence of pyrogens }\end{array}$ & $\begin{array}{l}\text { - } \Sigma \mathrm{TR} \leq 1.3^{\circ} \mathrm{C} \\
\text { - Pyrogen-negative }\end{array}$ & $\begin{array}{l}\text {. } \Sigma \mathrm{TR}(\mathrm{n}=3,6,9 \text { or } 12) \\
\leq 1.15,2.80,4.45 \text { or } \\
6.60\left({ }^{\circ} \mathrm{C}\right) \text { respectively } \\
\text { - Product passes }\end{array}$ \\
\hline Case 2 and judgment & $\begin{array}{l}\text { - } 1 \text { or } 2 \text { individual TR } \geq 0.6^{\circ} \mathrm{C} \\
\text { or } \Sigma \text { TR }(\mathrm{n}=3)>1.4^{\circ} \mathrm{C} \\
\text { - Test } 5 \text { other rabbits }\end{array}$ & $\begin{array}{l}\text { - Any individual TR } \geq 0.5^{\circ} \mathrm{C} \\
\text { - Test } 5 \text { other rabbits }\end{array}$ & $\begin{array}{l}\text { - } \Sigma \mathrm{TR}>2.5^{\circ} \mathrm{C} \\
\text { - Pyrogen-positive }\end{array}$ & $\begin{array}{l}\text { - } \Sigma \text { TR }(\mathrm{n}=3,6,9 \text { or } 12) \\
>2.65,4.30,5.95 \text { or } \\
6.60\left({ }^{\circ} \mathrm{C}\right) \text { respectively } \\
\text { - Product fails }\end{array}$ \\
\hline Case 3 and judgment & $\begin{array}{l}\text { - Not more than } 3 \text { of the TR } \\
(\mathrm{n}=8) \geq 0.6^{\circ} \mathrm{C} \text { and } \Sigma \mathrm{TR} \\
(\mathrm{n}=8) \leq 3.7^{\circ} \mathrm{C} \\
\text { - Absence of pyrogens }\end{array}$ & $\begin{array}{l}\text { - Not more than } 3 \text { of the } \\
\text { TR }(n=8) \geq 0.5^{\circ} \mathrm{C} \text { and } \Sigma \mathrm{TR} \\
(\mathrm{n}=8) \leq 3.3^{\circ} \mathrm{C} \\
\text { - Absence of pyrogens }\end{array}$ & $\begin{array}{l}-1.3^{\circ} \mathrm{C}<\Sigma \mathrm{TR}<2.5^{\circ} \mathrm{C} \\
\text { - Test } 3 \text { other rabbits }\end{array}$ & $\begin{array}{l}\text { - } \Sigma \text { TR does not meet } \\
\text { neither case } 1 \text { nor case } 2 \\
\text { - Test } 3 \text { other rabbits } \\
\text { up to } 12\end{array}$ \\
\hline Case 5 and judgment & - & - & $\begin{array}{l}\text { - } \sum \mathrm{TR}(\mathrm{n}=6)>4.2^{\circ} \mathrm{C} \\
\text { - Pyrogen-positive }\end{array}$ & - \\
\hline Case 6 and judgment & - & - & $\begin{array}{l}-3.0^{\circ} \mathrm{C}<\Sigma \mathrm{TR} \\
(\mathrm{n}=6)<4.2^{\circ} \mathrm{C} \\
\text {. Test } 3 \text { other rabbits }\end{array}$ & - \\
\hline Case 7 and judgment & - & - & $\begin{array}{l}\text { - } \Sigma \mathrm{TR}(\mathrm{n}=9) \leq 5.0^{\circ} \mathrm{C} \\
\text { - Pyrogen-negative }\end{array}$ & - \\
\hline Case 8 and judgment & - & - & $\begin{array}{l}\text {. } \Sigma \mathrm{TR}(\mathrm{n}=9)>5.0^{\circ} \mathrm{C} \\
\text { - Pyrogen-positive }\end{array}$ & - \\
\hline
\end{tabular}

TR. Rabbit temperature rise; IP: International Pharmacopoeia; USP: United States Pharmacopoeia; JP: Japanese Pharmacopoeia; EP: European Pharmacopoeia.

Regarding the acceptance criteria and judgement, the main differences are the number of rabbits in the extra-group and above all, the acceptance criteria.

It should be noted that the USP and the EP make some remarks about the number of rabbits, the overall treatment of the rabbits, and the replacement of the rabbit pyrogen test by an "in vitro" test. In addition, the USP is the only test to give instructions for pyrogen testing of medical devices, injection assemblies and radioactive pharmaceuticals.

\section{In Vitro Pyrogen Assay: Bacterial Endotoxins Test (BET)}

Bacterial Endotoxins Test is completely harmonized according to the Q4B annex 14 published by the ICH in 2012 [29]. In the IP and USP there are three possible alternatives: The gel-clot technique, which is based on gel formation; the turbidimetric technique, based on the development of turbidity after cleavage of an endogenous substrate; and the chromogenic technique, based on the development of color after cleavage of a synthetic peptide-chromogen complex [30,31]. The JP outlines two detailed assays: the gel-clot techniques, which are based on gel formation by the reaction of the lysate TS with endotoxins and the photometric techniques, based on endotoxin-induced optical changes of the lysate TS. In the EP and related pharmacopoeias (The British Pharmacopoeia (BP), Real Farmacopea Española (RFE), etc.), six methods are described: Method A, or gel-clot method limit test; method B or gel-clot method quantitative test; method $\mathrm{C}$, or turbidimetric kinetic method; method D or chromogenic kinetic method; method E, or chromogenic end-point method; and method F, or turbidimetric end-point method [32,33]. In all the pharmacopoeias, the gel-clot limit test should be used if there are doubts about the results of the other proposed methods. 
Regarding the apparatus, reagents, test solutions and determination of maximum valid dilution (MVD), no differences between the four pharmacopoeias can be determined. Authors only find little variations between JP and the other pharmacopoeias in some specific points (Tables 5 and S1-S3).

Table 5. Differences in harmonized bacterial endotoxins test (BET) between JP and IP, USP and EP.

\begin{tabular}{|c|c|c|}
\hline Experimental & IP-USP-EP & JP \\
\hline $\begin{array}{l}\text { Gel-clot techniques: } \\
\text { valid test conditions }\end{array}$ & $\begin{array}{l}\text { The lowest concentration of the standard } \\
\text { solutions shows a (-) result }\end{array}$ & $\begin{array}{l}\text { When } 0.25 \lambda \text { of the standard solution } \\
\text { shows a (-) result }\end{array}$ \\
\hline $\begin{array}{l}\text { Photometric quantitative } \\
\text { techniques: requirements }\end{array}$ & $\begin{array}{l}\text { - Sol. C comply assurance of criteria } \\
\text { - endotoxin recovery: } 50-200 \% \\
\text { - Sol. D: } \leq \text { blank value of the lysate } \\
\text { employed or < endotoxin detection limit }\end{array}$ & $\begin{array}{l}\text { - }|\mathrm{r}| \text { of sol. C: } \geq 0.980 \\
\text { - endotoxin recovery: } 50-200 \% \\
\text { - Sol. D: } \leq \text { blank value of the lysate } \\
\text { employed or }<\text { endotoxin detection limit }\end{array}$ \\
\hline
\end{tabular}

IP: International Pharmacopoeia; USP: United States Pharmacopoeia; JP: Japanese Pharmacopoeia; EP: European Pharmacopoeia.

\section{Conclusions}

The RPT is not harmonized between the IP and the ICH pharmacopoeias (JP, USP and EP). There are important differences in the design, procedure, temperature recording, acceptance criteria and judgement. Although the current thinking of the regulatory authorities is the transition from the in vivo test to a validated in vitro test, such as the LAL-test in accordance with 21 CFR 610.9. Nowadays, the only way for some products to demonstrate apyrogenicity during the preclinical phase is the RPT, especially if the risk assessment indicates that non-endotoxin pyrogens may be present. In Europe, the EP has an alternative test to the rabbit test. This is the monocyte activation test, a whole blood assay. Thus, pharmaceutical laboratories should consider these differences in their dossiers.

The harmonized ICH-BET, the most popular quality control endotoxin test, has as expected no significant differences across the published official monographs, and all of them may be considered interchangeable. Nevertheless, the pharmaceutical companies should demonstrate to the regulatory authorities that the selected method is acceptable and suitable for a specific material or formulation.

Supplementary Materials: The following is available online at http:/ /www.mdpi.com/2072-6651/10/8/331/s1, Table S1: Comparative analysis of the BET conditions between IP, USP, JP, EP and also BP and RFE, Table S2: Comparative analysis of the Gel-clot techniques between IP, USP, JP, EP and also BP and RFE, Table S3: Comparative analysis of the Photometric quantitative techniques between IP, USP, JP, EP and also BP and RFE.

Author Contributions: M.C.-D. and D.C.D conceived and designed this manuscript; V.G.-R. and E.F. collected and analyzed the pharmacopeial monographies; M.C.-D., P.J., T.G. and M.G. contributed to the critical reading of the draft manuscript; V.G.-R., E.F. and D.C.-D. wrote the paper; T.G., M.C.-D. and D.C.-D. reviewed the manuscript.

Funding: This research received no external funding.

Acknowledgments: We thank J.E. Basterrechea for technical assistance.

Conflicts of Interest: The authors declare no conflict of interest. The funders had no role in the design of the study; in the collection, analyses, or interpretation of data; in the writing of the manuscript, and in the decision to publish the results.

\section{References}

1. Sandel, T. Assesing non-endotoxin microbial pyrogens in relation in pharmaceutical processing. J. GXP Compliance 2015, 19, 1-12.

2. Tours, N.; Sandle, T. Comparison of dry-heat depyrogenation using three different types of Gram-negative bacterial endotoxin. Eur. J. Parenter. Pharm. Sci. 2008, 13, 17-20.

3. Ensor, D.S.; Foarde, K.K. The behavior of particles in cleanrooms. In Environmental Monitoring for Cleanrooms and Controlled Environments, 1st ed.; Dixon, A.M., Ed.; CRC Press Taylor \& Francis: Boca Raton, FL, USA, 2016; pp. 1-28; ISNB 0-8247-2359-7.

4. Seibert, F.B. The cause of many febrile reactions following intravenous injections. I. Am. J. Physiol. 1925, 71, 621-651. [CrossRef] 
5. Welch, H.; Calvery, H.D.; McClosky, W.T.; Price, C.W. Method of preparation and test for bacterial pyrogens. J. Am. Pharm. Assoc. 1943, 32, 65-69. [CrossRef]

6. McClosky, W.T.; Price, C.W.; Van Winkle, W.J.; Welch, H.; Calvery, H.O. Results of the first USP collaborative study of pyrogens. J. Am. Pharm. Assoc. 1943, 32, 69-73. [CrossRef]

7. Levin, J.; Bang, F.B. A description of cellular coagulation in the limulus. Bull. Johns Hopkins Hosp. 1964, 115, 337-345. [PubMed]

8. Levin, J.; Bang, F.B. The role of endotoxin in the extracellular coagulation of limulus blood. Bull. Johns Hopkins Hosp. 1964, 115, 265-274. [PubMed]

9. Altintas, Z.; Abdin, M.J.; Tothill, A.M.; Karim, K.; Tothill, I.E. Ultrasensitive detection of endotoxins using computationally designed nanoMIPs. Anal. Chem. Acta 2016, 935, 239-248. [CrossRef] [PubMed]

10. Solano, G.; Gómez, A.; León, G. Assessing endotoxins in equine-derived snake antivenoms: Comparison of the USP pyrogen test and the Limulus Amoebocyte Lysate assay (LAL). Toxicon 2015, 105, 13-18. [CrossRef] [PubMed]

11. Fingola, F.F.; Albertino, S.R.G.; Abrantes, S.M.P.; Zamith, H.P.S. Intralaboratory validation of kinetic chromogenic Limulus amebocyte lysate assay for bacterial endotoxin determination in anti-bothropic serum. J. Pharm. Biomed. Anal. 2013, 85, 93-98. [CrossRef] [PubMed]

12. Kalita, P.; Chaturvedula, L.M.; Sritharan, V.; Gupta, S. In vitro flow-through assay for rapid detection of endotoxin in human sera: A proof-of-concept. Nanomed. Nanotechnol. Biol. Med. 2017, 13, 1483-1490. [CrossRef] [PubMed]

13. Mujika, M.; Zuzuarregui, A.; Sánchez-Gómez, S.; Martínez de Tejada, G.; Arana, S.; Pérez-Lorenzo, E. Screening and selection of synthetic peptides for a novel and optimized endotoxin detection method. J. Biotechnol. 2014, 186, 162-168. [CrossRef] [PubMed]

14. Caldeira da Siva, C.; Franca Presgrave, O.A.; Hartung, T.; Lage de Moraes, A.M.; Fernandes Delgado, I. Applicability of the Monocyte Activation Test (MAT) for hyperimmune sera in the routine of the quality control laboratory: Comparison with the Rabbit Pyrogen Test (RPT). Toxicol. Vitr. 2016, 32, 70-75.

15. Reich, J.; Lang, P.; Grallert, H.; Motschmann, H. Masking of endotoxin in surfactant samples: Effects on Limulus-based detection systems. Biologicals 2016, 44, 417-422. [CrossRef] [PubMed]

16. Bolden, J.; Knight, M.; Stockman, S.; Omokoko, B. Results of a harmonized endotoxin recovery study protocol evaluation by 14 BioPhorum Operations Group (BPOG) member companies. Biologicals 2017, 48, 74-81. [CrossRef] [PubMed]

17. Jin, Y.; Jia, J.; Li, C.; Xue, J.; Sun, J.; Wang, K.; Gan, Y.; Xu, J.; Shi, Y.; Liang, X. LAL test and RPT for endotoxin detection of CPT-11/DSPE-mPEG2000 nanoformulation: What if traditional methods are not applicable? Asian J. Pharm. Sci. 2018, in press. [CrossRef]

18. 2.6.30. Monocyte Activation Test. In European Pharmacopeia 9.0., 9th ed.; Council of Europe: Strasbourg, France, 2017; pp. 193-194; ISNB 978-9-2871-8133-6.

19. Guidance for Industry Pyrogen and Endotoxins Testing: Questions and Answers. U.S. Food and Drug Administration. 2012. Available online: www.fda.gov/Drugs/GuidanceComplianceRegulatoryInformation/ Guidances/default.htm (accessed on 3 August 2018).

20. Hartung, T.; Wendel, A. Detection of Pyrogens using human whole blood. Altex 1995, 12, 70-75. [PubMed]

21. Schindler, S.; von Aulock, S.; Daneshian, M.; Hartung, T. Development, validation and applications of the monocyte activation test for pyrogens based on human whole blood. Altex 2009, 26, 265-277. [CrossRef] [PubMed]

22. Hoffmann, S.; Peterbauer, A.; Schindler, S.; Fennrich, S.; Poole, S.; Mistry, Y.; Montag-Lessing, T.; Spreitzer, I.; Löschner, B.; Van Aalderen, M.; et al. International validation of novel pyrogen tests based on human monocytoid cells. J. Immunol. Methods 2005, 298, 161-173. [CrossRef] [PubMed]

23. De Mattos, K.A.; Navega, E.C.A.; Silva, V.F.; Almeida, A.S.; Da Silva, C.C.; Presgrave, O.A.F.; Junior, D.D.S.G.; Delgado, I.F. Applicability of the monocyte activation test (MAT) in the quality control of the 17DD yellow fever vaccine. Altern. Lab. Anim. 2018, 46, 23-37. [PubMed]

24. Nordgren, I.K. Leukoreduction system chambers provide a valuable source of functional monocytes for the monocyte activation test by comparison with internationally validated methods. J. Immunol. Methods 2016, 428, 42-49. [CrossRef] [PubMed]

25. <151> Pyrogen Test. In U.S. Pharmacopeia 41; United States Pharmacopeial Convention, Inc.: Rockville, MD, USA, 2018; pp. 6083-6085; ISNB 978-3-7692-7022-8. 
26. 2.6.8. Pyrogens. In European Pharmacopeia 9.0., 9th ed.; Council of Europe: Strasbourg, France, 2017; pp. 193-194; ISNB 978-9-2871-8133-6.

27. 4.04 Pyrogen Test. In The Japanese Pharmacopoeia, 17th ed; The Ministry of Health, Labour and Welfare: Tokyo, Japan, 2016; pp. 120-194. Available online: www.pmda.go.jp/english (accessed on 23 May 2018).

28. 3.4 Test for bacterial endotoxins. In The International Pharmacopoeia, 7th ed.; WHO Department of Essential Medicines and Health Products: Geneva, Switzerland, 2017. Available online: www.who.int/phint/ (accessed on 21 May 2018).

29. Evaluation and Recommendation of Pharmacopoeial Texts for Use in the ICH Regions on Bacterial Endotoxins Test. General Chapter. Q4b Annex 14. International Conference on Harmonisation of Technical Requirements for Registration of Pharmaceuticals for Human Use, 2012. Available online: www.ich.org (accessed on 30 May 2018).

30. 3.5 Test for pyrogens. In The International Pharmacopoeia, 7 th ed.; WHO Department of Essential Medicines and Health Products: Geneva, Switzerland, 2017. Available online: www.who.int/phint/ (accessed on 21 May 2018).

31. $<85>$ Bacterial Endotoxins Test. In U.S. Pharmacopeia 41; United States Pharmacopeial Convention, Inc.: Rockville, MD, USA, 2018; pp. 6011-6017; ISNB 978-3-7692-7022-8.

32. 4.01 Bacterial Endotoxins Test. In the Japanese Pharmacopoeia, 17th ed.; The Ministry of Health, Labour and Welfare: Tokyo, Japan, 2016; pp. 110-114. Available online: www.pmda.go.jp/english (accessed on 23 May 2018).

33. 2.6.14. Bacterial Endotoxins. In European Pharmacopeia 9.0., 9th ed.; Council of Europe: Strasbourg, France, 2017; pp. 204-207; ISNB 978-9-2871-8133-6.

(C) 2018 by the authors. Licensee MDPI, Basel, Switzerland. This article is an open access article distributed under the terms and conditions of the Creative Commons Attribution (CC BY) license (http:/ / creativecommons.org/licenses/by/4.0/). 